\title{
Investigation of the Relationship Between Biochemical Parameters, Alexithymia, and Stress Levels in Hemodialysis Patients
}

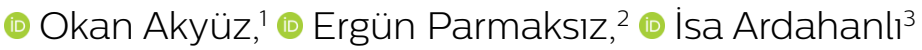

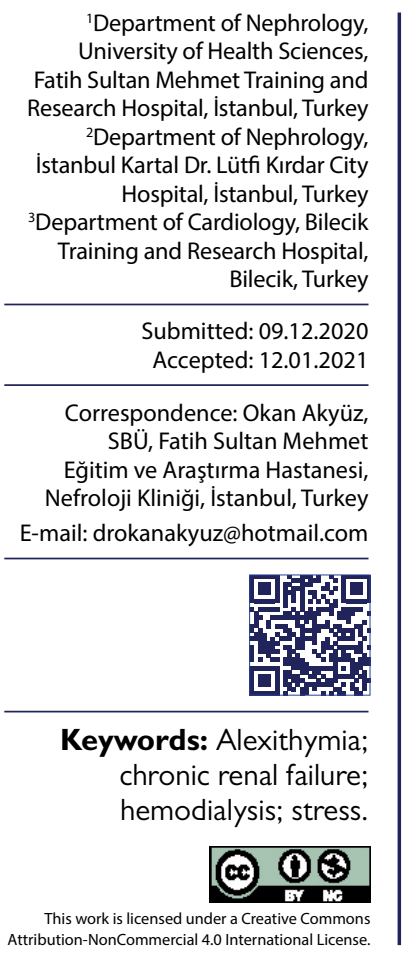

\begin{abstract}
Objective: Hemodialysis is a treatment modality for patients, in which physical and psychological stress factors are together. Intense anxiety and stress caused by treatment are very favorable for alexithymic feelings. Hemodialysis patients undergo continuous biochemical changes hemodynamically. Our aim in this study was to investigate the relationship between biochemical parameters; we use in hemodialysis patients' follow-up and alexithymic emotions and stress factors.
\end{abstract}

Methods: Fifty-one patients who received hemodialysis treatment due to end-stage renal failure in Bilecik Province in 2019 were included in the study. Routine biochemical follow-up data of patients, hemodialysis stressor scale, and Toronto alexithymia scale (TAS) were used in the study. The statistical significance level was determined as $p<0.05$ between routinely monitored hemodialysis parameters and scales.

Results: It was observed that $58.8 \%$ of the patients included in the study were alexithymic. The mean hemodialysis stressor was 86.6 , and the mean TAS was 62.76 . The high levels of stress and alexithymic emotion scales in hemodialysis patients were noted. A significant relationship was found between inlet creatinine, urea reduction ratio, $\mathrm{Kt} / \mathrm{V}$, dry weight, albumin, output urea, and calcium between the hemodialysis stress scale and TAS subgroups.

Conclusion: Psychiatric evaluation should be routine in the follow-up of hemodialysis patients, and the monthly psychologist/psychiatric examination, which was abolished with the last regulation change, should be restarted. It is also essential to increase the awareness of health-care professionals working in the dialysis unit about coping with stress and stressful patient management.

\section{INTRODUCTION}

The high prevalence and clinical significance of depression in end-stage renal disease (ESRD) have led to research and clinical interest in identifying risk and protective factors for depression. Studies aiming to determine the factors that can predict the susceptibility to develop depression in ESRD patients are critical in obtaining higher patient resilience and better health outcomes. ${ }^{[1-3]}$ Sudden biochemical changes in hemodialysis treatment, prolonged inactivity, dependence on the machine, intensive and continuous medication, sleep problems, difficulties in accessing the dialysis unit, intensive diet, and fluid restriction predispose to the emergence of physical and psychological pathologies in patients. ${ }^{[4-6]}$

Alexithymia is a personality structure characterized by the inability to define emotions and express them ver- bally. ${ }^{[7]}$ Meaning "no words for emotions," alexithymia suggests that for some scientists, there may be difficulty in expressing emotions verbally, but also a deficiency in cognitive processing. This will cause emotions to remain undifferentiated and poorly regulated and predispose alexithymic individuals to be psychological and somatic disorders. ${ }^{[8]}$ The inability of alexithymic individuals to express their feelings predisposes them to both psychological and somatic symptoms. Alexithymia is widely associated with health problems. ${ }^{[9]}$ Studies suggest that patients who receive hemodialysis treatment have moderate depression, and more than half of them are alexithymic. ${ }^{[10]}$ Studies have reported that half of the patients who received hemodialysis treatment were alexithymic regardless of gender. The comparison they made with healthy individuals and cancer patients had higher alexithymia in patients receiving hemodialysis. ${ }^{[1]}$ 


\section{MATERIALS AND METHODS}

Fifty-one volunteer patients with ESRD who received hemodialysis treatment were included in the study. The same person conducted the questionnaires in the form of face-to-face interviews by the researcher. This study approved by the Bilecik Provincial Health Directorate Scientific Research Permits Application Review Commission (date: 15.04.2020, no: 2020/015).

\section{Study inclusion criteria}

The following criteria were included in the study:

- Patients over 18 years old

- Patients on hemodialysis for at least 6 months

- Patients who can read and write and complete the informed consent form.

The patients' demographic data and biochemical parameters were obtained by scanning retrospectively from the computer network in the hospital hemodialysis unit.

The exclusion criteria were the use of antistress and anxiety medicines, tumor or metastasis disaster experienced during the past 6 months, and peritoneal dialysis or a kidney transplant procedure.

Hemodialysis stress scale (HSS): We used a demographic information record sheet and HSS (HSS: Baldriee, Murphy, and Powers, 1982) to collect the data. HSS is a self-report measurement composed of 29 specific items (six physiological and 23 psychosocial stressors). Responses indicated item intensity through a 4-point Likert-scale: No stress (0), less stress (1), low stress (2), the average stress (3), and high stress. The patients were asked to mark every item in the questionnaire based on severity. The total score of HSS is between 0 and 116 and depends on patients' response and is categorized into three levels: Low stress (0-40), the average stress (4I-80), and high stress $(8|-||| 6){ }^{[12]}$

The Toronto Alexithymia Scale (TAS-20): It is a scale that investigates alexithymia, which is defined as not recognizing one's own emotions and excitement. TAS20 is a Likert-type self-assessment scale that consists of twenty items, scored between I (never disagree) and 5 (always agree). Items 4, 5, 10, 18, and 19 are scored in reverse. The difficulty recognizing emotions (TAS-I) subscale consists of seven items (items I, 3, 6, 7, 9, 13, and 14) and is defined as difficulty identifying emotions and distinguishing them from bodily sensations accompanying emotional arousal. The difficulty expressing feelings (TAS2) subscale consists of five items (items $2,4,11,12$, and 17) and is defined as difficulty conveying emotions to others. The extroverted thinking (TAS-3) subscale consists of eight items (items 5, 8, 10, 15, 16, 18, 19, and 20), and the presence of an extroverted cognitive structure is defined as the weakness of introverted thinking and imagination power. Participants were asked to mark the most appropriate of "Never," "Rarely," "Sometimes," "Often," and
"Always" for each question. High scores indicate a high level of alexithymia. This scale was developed by Bagby et al. (1994), and Turkish adaptation was made by Gulec et al. (2009). The cutoff value of TAS-20 is 51 or less, with 52-60 indicating possible alexithymia and a score of $>6$ I indicating alexithymia. ${ }^{[13]}$

\section{Statistical analysis}

Descriptive statistics were used to define continuous variables (mean, standard deviation, minimum, median, and maximum). Comparison of two independent variables and not compatible with normal distribution was made with the Mann-Whitney U-test. Comparison of more than two independent variables and not consistent with normal distribution was created with the Kruskal-Wallis test. The correlation between continuous variables that do not conform to normal distribution was analyzed with the Spearman Rho Correlation Coefficient. The analyses were performed using the MedCalc Statistical Software version I 2.7.7 (MedCalc Software bvba, Ostend, Belgium) Program. Statistical significance level was determined as $p<0.05$.

\section{RESULTS}

Among the HD patients, 34 (66.7\%) were male, and 17 (33.3\%) female. The average age was $65.14 \pm 11.30$. The minimum and maximum age was 35 and 85 , respectively.

When the alexithymia levels of subjects participating in the study were examined, it was found that $58.8 \%(n=30)$ were alexithymic (Table I).

Hemodialysis durations were $43.1 \%(n=22)$ for 6 months to 2 years, $37.3 \%(n=19)$ for $2-5$ years, and $19.6 \%(n=10)$ for $>5$ years (Table 2). There is no statistically significant difference between gender and HSS, HSS subscales, TAS20 , and TAS-20 subscales. There is no statistically significant difference between the duration of hemodialysis and HSS, HSS subscales, TAS-20, and TAS-20 subscales. The relationship between the subscales of demographic data, HSS, HSS subscales, TAS-20, and TAS- 20 subscales is shown in Table 2.

The biomarkers values, ultrafiltration amount, urea reduction ratio (URR), Kt/V, and dry weight of the subjects who participate in the study were evaluated (Table 3).

There is a statistically significant negative moderate correlation between HSS and UF $(p=0.004)$. There is statistically significant positive moderate correlation between HSS-I and calcium level $(r=0.283, p=0.044)$. There is

Table I. Percentage distributions, according to alexithymia levels of hemodialysis patients

\begin{tabular}{lcc}
\hline & $\mathbf{n = 5}$ I & $\%$ \\
\hline No alexithymia (5I points and below) & I & 2.0 \\
Possible alexithymia (52-60 points) & 20 & 39.2 \\
Alexithymia (6I points and above) & 30 & 58.8 \\
\hline
\end{tabular}




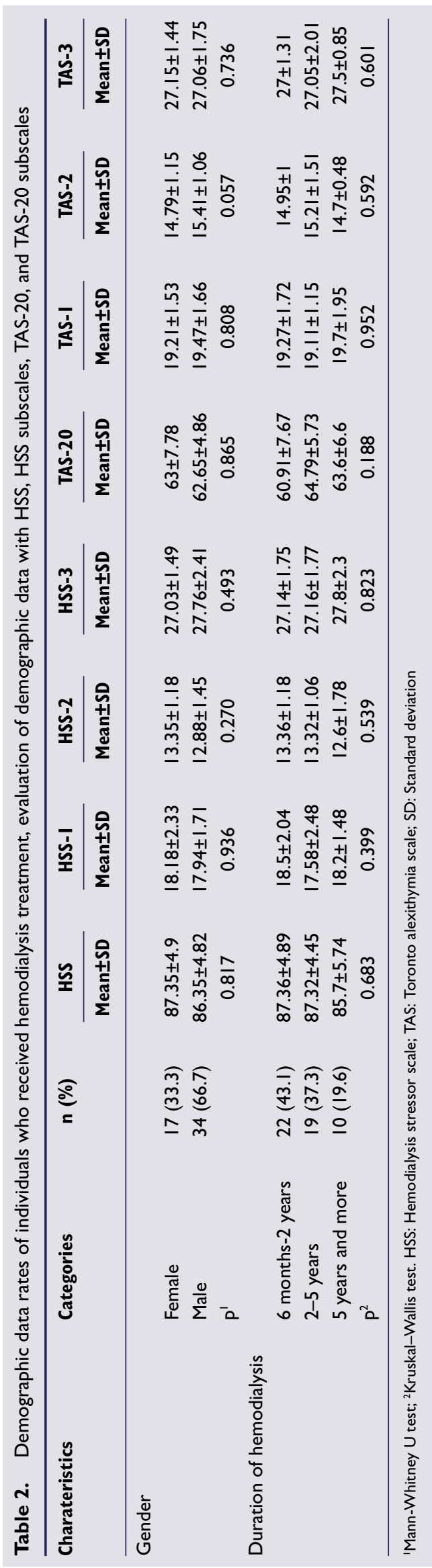

a statistically significant negative moderate correlation between TAS-20 and dialysis output urea value, serum phosphorus level $(p=0.026, p=0.010)$. There is statistically significant negative weak correlation between TAS-20 and dry weight $(r=-0.284, p=0.044)$. There is statistically significant positive weak correlation between TAS-I and albumin ( $r=0.28 \mathrm{I}, \mathrm{p}=0.046)$.

There is statistically significant negative weak correlation between TAS- 3 and input creatinine value, dialysis input potassium level and ultrafiltration $(p=0.050, p=0.044$, and $\mathrm{p}=0.039$ ).

There is statistically significant positive moderate correlation between TAS-3 and URR, Kt/V ( $p=0.00 \mathrm{I}, \mathrm{p}=0.388)$.

\section{DISCUSSION}

Although biochemical monitoring markers play a central role in successfully treating ESRD patients, it is insufficient to understand the patients' overall disease burden fully.

In general, all chronic illnesses are associated with many psychological pathologies. The frequency of psychosocial disorders will increase in hemodialysis patients due to sociological factors such as diet and fluid restrictions, time spent on dialysis, access to the dialysis center, and continuously variable hemodynamic status. Both the literature and the results of our study show that alexithymia is observed at a high level. In our research, it is seen that individuals with alexithymia are incredibly high (58.8\%). Like our study, Pop-Jordanovam and Polenakovic reported that half of the patients who received hemodialysis treatment in Macedonia appeared to be alexithymic. ${ }^{[1]}$

Katon proposed a conceptual model of the interaction between depression and medical illness. ${ }^{[14]}$ According to this model, we assume that depression and ESRD interact at three levels. First, depression can contribute to chronic kidney disease progression to chronic kidney failure through parallel inflammatory pathways. Second, the lack of well-being associated with ESRD leads to depression while at the same time exacerbating the impact of ESRD on physical function, quality of life, and perceived physical symptom burden. Third, depression is associated with worse disease outcomes with non-compliance with treatment and malnutrition. ${ }^{[14]}$ These theoretical interactions are supported by the observations that depression is associated with early dialysis treatment initiation. ${ }^{[15,16]}$ Our study found a positive correlation between input creatinine and alexithymia scores in the group with high levels. A study found that low albumin and hemoglobin are unrelated to serum urea creatinine, which makes stress management difficult, and in our study, we found the opposite. ${ }^{[17]}$

HSS scores were significantly lower in patients with a high amount of ultrafiltration. Fluid intake is among the major causes of anxiety in hemodialysis patients. Patients usually want as much ultrafiltration as possible in dialysis because this allows patients to drink more easily between two hemodialysis sessions and causes them to move freer in 
Table 3. Assessment of the relationship between biomarkers, total score average of TAS-20, total mean score of HSS, and the number of daily medicines used by HSS, HSS subscales, TAS-20, and TAS- 20 subscales

\begin{tabular}{|c|c|c|c|c|c|c|c|c|c|}
\hline & & HSS & HSS-I & HSS-2 & HSS-3 & TAS-20 & TAS-I & TAS-2 & TAS-3 \\
\hline \multirow[t]{2}{*}{ HSS } & $r$ & & & & & 0.138 & 0.102 & -0.123 & 0.007 \\
\hline & $P$ & & & & & 0.335 & 0.474 & 0.391 & 0.961 \\
\hline \multirow[t]{2}{*}{ TAS-20 } & $r$ & 0.138 & -0.223 & 0.093 & -0.205 & & & & \\
\hline & $P$ & 0.335 & 0.116 & 0.516 & 0.150 & & & & \\
\hline \multirow[t]{2}{*}{ Hemoglobin (g/dL) } & $r$ & 0.059 & 0.047 & -0.140 & 0.107 & -0.027 & -0.110 & -0.024 & -0.163 \\
\hline & $P$ & 0.682 & 0.743 & 0.328 & 0.453 & 0.851 & 0.441 & 0.869 & 0.253 \\
\hline \multirow[t]{2}{*}{ Dialysis urea output (mg/dL) } & $r$ & 0.176 & -0.018 & 0.035 & 0.041 & $-0.312^{*}$ & -0.082 & -0.158 & -0.262 \\
\hline & $P$ & 0.216 & 0.902 & 0.810 & 0.776 & 0.026 & 0.565 & 0.269 & 0.063 \\
\hline \multirow[t]{2}{*}{ Dialysis urea input (mg/dL) } & $r$ & 0.222 & -0.072 & 0.039 & -0.037 & -0.226 & 0.011 & -0.131 & -0.021 \\
\hline & $P$ & 0.118 & 0.616 & 0.783 & 0.796 & 0.111 & 0.940 & 0.361 & 0.882 \\
\hline \multirow[t]{2}{*}{ Albumin (g/dL) } & $r$ & -0.103 & -0.077 & 0.043 & -0.173 & 0.143 & $0.281^{*}$ & 0.113 & 0.192 \\
\hline & $P$ & 0.473 & 0.592 & 0.762 & 0.224 & 0.318 & 0.046 & 0.432 & 0.178 \\
\hline \multirow[t]{2}{*}{ Phosphorus (mg/dL) } & $r$ & 0.075 & 0.052 & 0.008 & 0.162 & $-0.356^{*}$ & -0.002 & -0.119 & -0.131 \\
\hline & $\mathrm{P}$ & 0.599 & 0.719 & 0.957 & 0.256 & 0.010 & 0.987 & 0.407 & $0.36 \mathrm{I}$ \\
\hline \multirow[t]{2}{*}{ Calcium (mg/dL) } & $r$ & -0.170 & $0.283^{*}$ & -0.094 & 0.152 & -0.201 & -0.094 & 0.263 & -0.206 \\
\hline & $P$ & 0.234 & 0.044 & 0.513 & 0.289 & 0.156 & 0.511 & 0.062 & 0.148 \\
\hline \multirow[t]{2}{*}{ Input creatinine (mg/dL) } & $r$ & 0.073 & 0.030 & -0.004 & -0.046 & -0.230 & -0.027 & -0.007 & -0.276 \\
\hline & $P$ & 0.613 & 0.837 & 0.976 & 0.749 & 0.104 & 0.852 & 0.960 & 0.050 \\
\hline \multirow[t]{2}{*}{ Input potassium (mEq/L) } & $r$ & 0.144 & 0.062 & -0.140 & -0.038 & -0.074 & 0.138 & 0.082 & $-0.283^{*}$ \\
\hline & $P$ & 0.313 & 0.664 & 0.328 & 0.793 & 0.604 & 0.336 & 0.567 & 0.044 \\
\hline \multirow[t]{2}{*}{ URR } & $r$ & 0.074 & -0.073 & -0.021 & -0.117 & 0.157 & 0.110 & 0.001 & $0.451^{* *}$ \\
\hline & $P$ & 0.605 & 0.608 & 0.881 & 0.415 & 0.272 & 0.442 & 0.995 & 0.001 \\
\hline \multirow[t]{2}{*}{$\mathrm{Kt} / \mathrm{V}$} & $r$ & 0.070 & -0.036 & -0.005 & -0.117 & 0.152 & 0.147 & 0.016 & $0.388^{* *}$ \\
\hline & $\mathrm{P}$ & 0.626 & 0.800 & 0.975 & 0.412 & 0.287 & 0.305 & 0.913 & 0.005 \\
\hline \multirow[t]{2}{*}{ C-reactive protein $(\mathrm{mg} / \mathrm{dL})$} & $r$ & 0.039 & -0.073 & -0.103 & -0.045 & 0.170 & 0.068 & 0.119 & -0.056 \\
\hline & $P$ & 0.787 & 0.615 & 0.478 & 0.754 & 0.237 & 0.640 & 0.410 & 0.698 \\
\hline \multirow[t]{2}{*}{ Ferritin (ng/mL) } & $r$ & -0.046 & -0.143 & -0.262 & -0.166 & -0.061 & 0.155 & -0.138 & 0.130 \\
\hline & $P$ & 0.751 & 0.322 & 0.066 & 0.249 & 0.675 & 0.282 & 0.339 & 0.370 \\
\hline \multirow[t]{2}{*}{ Parathormone (pg/mL) } & $r$ & 0.006 & 0.124 & 0.075 & 0.005 & 0.111 & 0.153 & 0.120 & -0.184 \\
\hline & $P$ & 0.965 & 0.391 & 0.607 & 0.971 & 0.444 & 0.288 & 0.406 & 0.200 \\
\hline \multirow[t]{2}{*}{ Bicarbonate (mEq/L) } & $r$ & -0.086 & 0.004 & 0.140 & 0.005 & 0.100 & 0.082 & -0.080 & 0.034 \\
\hline & $P$ & 0.553 & 0.977 & 0.331 & 0.972 & 0.489 & 0.569 & 0.579 & 0.817 \\
\hline \multirow[t]{2}{*}{ Ultrafiltration amount (liter) } & $r$ & 0.017 & 0.162 & 0.030 & 0.088 & -0.247 & -0.039 & -0.122 & $-0.290^{*}$ \\
\hline & $\mathrm{P}$ & 0.906 & 0.257 & 0.833 & 0.539 & 0.080 & 0.786 & 0.393 & 0.039 \\
\hline \multirow[t]{2}{*}{ Dry weight (kg) } & $r$ & -0.143 & 0.083 & -0.062 & -0.052 & $-0.284^{*}$ & -0.130 & -0.039 & -0.157 \\
\hline & $P$ & 0.316 & 0.563 & 0.666 & 0.718 & 0.044 & 0.365 & 0.785 & 0.270 \\
\hline
\end{tabular}

Spearman's rho correlation test, ${ }^{*}<0.05,{ }^{* *}<0.001$. HSS: Hemodialysis stressor scale; TAS: Toronto alexithymia scale; URR: Urea reduction ratio.

their eating and drinking. Studies have suggested that the unstable hemodynamic environment during dialysis causes sudden changes in serum parameters, and the situation may affect psychiatric pathologies. ${ }^{[18,19]}$

We found no significant differences between sex and duration of hemodialysis between HSS, TAS, and their subgroups. Studies report that alexithymia is the primary psychiatric appearance accompanied by depression for 4 years or more in patients receiving hemodialysis treatment. We could not confirm this in our study. ${ }^{[19]}$ We attributed this to the patient group's proportional weight, whose dialysis duration was less than 5 years.

We found a negative correlation between the dialysis out- put urea value, serum phosphorus level, serum calcium, phosphorus product, and TAS-20 scores. A study conducted on 4000 patients with ESRD observed that there was no relationship between mental health and serum phosphorus and calcium-phosphorus product. ${ }^{[20]}$ In another study, individuals with calcium, phosphorus levels, and alexithymia were examined and showed an inverse correlation. ${ }^{[2]}$ Our results were different made us think that our study was due to its small scale and single center.

A cross-sectional analysis of 1545 dialysis patients enrolled in the hemodialysis (HEMO) study revealed that dialysis patients with low creatinine levels had a better life expectancy questionnaire. ${ }^{[22]}$ Similarly, in our study, TAS-3 scores 
were significantly higher in patients with high dialysis serum creatinine levels and increased iron and iron saturation with oxidant properties.

Especially TAS-3 scores were significantly higher in the group with high URR and $\mathrm{Kt} / \mathrm{V}$, which are the indicators of effective hemodialysis. In a study in the literature, it was observed that there was minimal change between effective hemodialysis and life expectancy questionnaires. ${ }^{[19,23]}$ In another study, no significant relationship was found between $\mathrm{Kt} / \mathrm{V}$ and cognitive function status, sleep function, sexual function, and body perception. ${ }^{[24]}$ It would be appropriate to conduct larger-scale studies to explain the pathophysiology of this relationship in this group with high hemodynamic variability.

As the dry weight of the patients decreased, alexithymia scores were significantly higher. This may be related to the weight loss caused by nutritional deficiency $(r=-0.284$, $\mathrm{p}=0.044$ ). Body mass index (BMI) and nutrition may be related. Studies with different results related to this and studies in different scales have been reported to reveal life expectancy and coping skills with BMI. ${ }^{[25,26]}$

\section{CONCLUSION}

Studies conducted on ESRD patients receiving hemodialysis treatment show that their perception of stress level associated with hemodialysis treatment is high, leading to a decrease in their quality of life and that they have difficulty coping with the disease. We think that controlling stressful factors for patients undergoing hemodialysis treatment and improving their ability to cope with stress will increase patients' compliance with treatment. We anticipate that very rapid correction of patients' biochemical parameters under hemodialysis treatment may contribute negatively to stress and psychology management. In the light of these data, we think that the compulsory monthly follow-up of psychologist/psychiatry, which was abolished with the latest regulation, should be restarted in dialysis centers.

Ethics Committee Approval

Approved by the Bilecik Provincial Health Directorate Scientific Research Permits Application Review Commission (date: 15.04.2020, no: 2020/0I5).

Peer-review

Internally peer-reviewed.

Authorship Contributions

Concept: O.A., I.A.; Design: O.A., E.P.; Supervision: E.P.,I.A.; Fundings: O.A., E.P.; Materials: O.A.; Data: O.A., I.A.; Analysis: E.P., I.A.; Literature search: O.A., E.P.; Writing: O.A., I.A.; Critical revision: O.A., E.P.

Conflict of Interest

None declared.

\section{REFERENCES}

1. Kitamura T, Shima S, Sugawara M, Toda MA. Clinical and psychosocial correlatesof antenatal depression: a review. Psychother Psy- chosom 1996;65:117-23. [CrossRef]

2. Ouimet MA, Primeau F, Cole MG. Psychosocial risk factors in poststrokedepression: a systematic review. Can J Psychiatry Rev Can Psychiatr 2001;46:819-28. [CrossRef]

3. Kupfer DJ, Frank E. Role of psychosocial factors in the onset of major depression. The integrative neurobiology of affiliation. New York: New York Academy of Sciences; 1997.p. 429-39. [CrossRef]

4. Sezer MT. Psychiatric Issues. Hemodialysis physician handbook. [Turkish]. Istanbul: Turkish Nephrology Society publication; 1997:147-52. Available at: http://www.nefroloji.org.tr/folders/file/ psikiyatrik_sorunlar.pdf. Accessed Feb 17, 2021.

5. Kara B. Adherence to treatment in hemodialysis patients: a multipleaspectapproach. Gulhane Tip Derg 2017;49:132-6.

6. Ibrahim S, El Salamony O, Ibrahim S, El Salamony O. Depression, quality of lifeand malnutrition-inflammation scores in hemodialysis patients. Am J Nephrol 2008;28:784-91. [CrossRef]

7. Sifneos PE. The prevalence of 'alexithymic' characteristicsin psychosomatic patients. Psychoter Psychosom 1973;22:255-62. [CrossRef]

8. Taylor G, Bagby R, Parker J. The alexithymia construct. Apotential paradigm for psychosomatic medicine. Psychosomatics 1991;32:15364. [CrossRef]

9. Saarijarvi S, Salminken JK, Tamminen T, Aarela E. Alexithymia in psychiatric consultation-liaison patients. Gen Hosp Psychiatry 1993;15:330-3. [CrossRef]

10. Senturk A, Levent BA, Tamam L. The psychopathology in patients with chronic renal failure treated with hemodialysis. [Turkish]. OMÜ Tip Dergisi 2000;17:163-72. [CrossRef]

11. Pop-Jordanova N, Polenakovic M. Alexithymia constructin dialysis patients. BANTAO Journal 2015;12:45-51. [CrossRef]

12. Kiani GA, Kermanshahi S, Ahmadi F. Study of the effect of Benson's relaxation technique on hemodynamic parameters and stress of discharge in acute myocardial infarction patients in Tehran, 2002. J Shaheed Sadoughi Univ Med Sci and Health Serv Yazd 2003;11:50-6.

13. Salbas E. The twenty-item Toronto Alexithymia Scale (TAS-20), 2016. Available at: http://www.ftronline.com/toronto-aleksitimi-olcegi/. Accessed May 20, 2017.

14. Katon WJ. Clinical and health services relationships between major depression, depressive symptoms, and general medical illness. Biol Psychiatry 2003;54:216-26. [CrossRef]

15. Hedayati SS, Minhajuddin AT, Afshar M, Toto RD, Trivedi MH, Rush AJ. Association between major depressive episodes in patients with chronic kidney disease and initiation of dialysis, hospitalization, or death. JAMA 2010;303:1946-53. [CrossRef]

16. Tsai YC, Chiu YW, Hung CC, Hwang SJ, Tsai JC, Wang SL, et al. Association of symptoms of depression with progression of CKD. Am J Kidney Dis 2012;60:54-61. [CrossRef]

17. Harwood L, Wilson B, Locking-Cusolito H, Sontrop J, Spittal J. Stressors and coping in individuals with chronic kidney disease. Nephrol Nurs J 2009;36:265-76, 301.

18. Griva K, Davenport A, Harrison M, Newman S. An evaluation of illness, treatment perceptions, and depression in hospital- vs. home-based dialysis modalities. J Psychosom Res 2010;69:363-70. [CrossRef]

19. Spiegel BMR, Melmed G, Robbins S, Esrailian E. Biomarkers and health-related quality of life in end-stage renal disease: a systematic review. Clin J Am Soc Nephrol 2008;3:1759-68. [CrossRef]

20. Tanaka M, Yamazaki S, Yahashino Y, Fukuhara S, Akiba T, Saito A, et al. Hypercalcaemia is associated with poor mental health in haemodialysis patients: results from Japan DOPPS. Nephrol Dial Transplant 2007;22:1658-64. [CrossRef]

21. Lai C, Aceto P, Luciani M, Fazzari E, Cesari V, Luciano S, et al. Emotional management and biological markers of dietetic regimen in chronic kidney disease patients. RenFail 2017;39:173-8. [CrossRef] 
22. Allen KL, Miskulin D, Yan G, Dwyer JT, Frydrych A, Leung J, et al; Hemodialysis (HEMO) Study Group. Association of nutritional markers with physical and mental health status in prevalent hemodialysis patients from the HEMO study. J Ren Nutr 2002;12:160-9. [CrossRef]

23. Merkus MP, Jager KJ, Dekker FW, de Haan RJ, Boeschoten EW, Krediet RT. Physical symptoms and quality of life in patients on chronic dialysis: Results of the Netherlands cooperative study on adequacy of dialysis (NECOSAD). Nephrol Dial Transplant 1999;14:1163-70. [CrossRef]

24. Korevaar JC, Merkus MP, Jansen MA, Dekker FW, Boeschoten EW,
Krediet RT. NECOSAD study group: Validation of the KDQOLSF: A dialysis-targeted health measure. Qual Life Res 2002;11:43747. [CrossRef]

25. Goller JL, McMahon JM, Rutledge C, Walker RG, Wood SE. Dialysis adequacy and self-reported health status in a group of CAPD patients. Adv Perit Dial 1997;13:128-33.

26. Kusek JW, Greene P, Wang SR, Beck G, West D, Jamerson K, et al. Cross-sectional study of health-related quality of life in African Americans with chronic renal insufficiency: The African American study of kidney disease and hypertension trial. Am J Kidney Dis 2002;39:513-24. [CrossRef]

\section{Hemodiyaliz Hastalarında Biyokimyasal Parametreler ile Aleksitimi ve Stres Düzeyleri Arasındaki Ilişsinin Araştırılması}

Amaç: Hemodiyaliz, hastalar için fiziksel ve psikolojik stres faktörlerinin bir arada olduğu bir tedavi modalitesidir. Tedavinin getirdiği yoğun kaygı ve stres aleksitimik duygular için oldukça elverişlidir. Aleksitimik bireyler duygu ve düşünceleri ifade etmekte zorlanma, kendisi ve çevresindeki fizyolojik değişimleri değerlendirememe ile karşı karşıyadır. Hemodiyaliz hastaları hemodinamik olarak sürekli biyokimyasal değişimlere uğrar. Çalışmadaki amacımız sürekli hemodiyaliz tedavisi altındaki hastalarda takipte kullandığımız biyokimyasal parametreler ile aleksitimik duygular ve stres faktörleri arasındaki ilişkiyi araştırmayı amaçladık.

Gereç ve Yöntem: Çalışmaya 2019 yılında Bilecik ilinde son dönem böbrek yetersizliği ile hemodiyaliz tedavisi alan 5 I gönüllü hasta alındı. Araştırmada hastaların rutin hemodiyaliz biyokimyasal takip verileri, hemodiyaliz stresör ölçeği ve Toronto alexitimi ölçeği kullanıldı. Rutin takip edilen hemodiyaliz parametreleri ve ölçekler arasında istatistiksel anlamlııı düzeyi $(p<0.05)$ olarak belirlendi.

Bulgular: Çalışmaya alınan bireylerin stres düzeylerinin oldukça yüksek olduğu görüldü. Hastaların \%58.8'nin aleksitimik olduğu anlaşıldı. Hastaların hemodiyaliz stresörü ortalaması 86.6, Toronto aleksitimi ölçeği ortalaması 62.76 olarak bulundu. Hemodiyaliz hastalarında stres ve aleksitimik duygu ölçeklerinin yüksekliği dikkat çekmiştir. Hemodiyaliz stresör ölçeği ve Toronto aleksitimi ölçek alt grupları arasında diyaliz giriş kreatinin, URR (üre azalma oranı), Kt/V, kuru ağırık, albümin, diyaliz çıkışüre ve kalsiyum arasında anlamlı ilişki saptanmıştır.

Sonuç: Hemodiyaliz hastalarının takibinde psikiyatrik değerlendirmenin rutin olması gerektiği, son yönetmelik değişikliği ile kaldırılan aylık psikolog/psikiyatri muayenesinin tekrar başlatılması gerektiği aşikardır. Diyaliz ünitesinde çalışan sağılık personelinin stresle başa çıkma ve stresli hasta yönetimi konularında farkındalığının arttırılması ayrıca önemlidir.

Anahtar Sözcükler: Aleksitimi; hemodiyaliz; kronik böbrek yetersizliğ; stres. 